УДК 37.013

DOI

Оксана Ісаєва, доктор педагогічних наук, професор кафедри педагогіки та інноваџійної освіти,

Національного університету “Львівська політехніка", доиент кафедри латинської та іноземних мов

Львівського національного медичного університету імені Данила Галицького Ганна Шайнер, кандидат педагогічних наук, доиент кафедри іноземних мов, Національного університету “Львівська політехніка"

\title{
ГУМАНІТАРНИЙ РОЗВИТОК СТУДЕНТІВ ЯК СКЛАДОВА СИСТЕМИ ВИЩОЇ ОСВІТИ
}

Гуманітарна освіта є одним із чинників формування морально-етичного світогляду особистості, оскільки враховує кониептуальні підходи до розуміння феноменів гуманізаиії та гуманітаризації.

Стратегія гуманітарного розвитку як актуальна проблема, базується на інтеграчійно-глобалізачійних процесах суспільства як складової формування иіннісних орієнтацій студентів. Гуманітарний розвиток, орієнтований на формування сучасної конкурентоспроможної особистості, розвиток та реалізаиію всіх їі здібностей, передбачає формування і розширення науково-філософського світогляду, сочіально-особистісних та професійних компетентностей. Визначено значущість особистості, ї̈ морально-етичні засади, окреслено сутність гуманітарного розвитку освіти для формування фахівијів вишів.

Ключові слова: гуманітарний розвиток; гуманітарні науки; вища освіта; гуманістичні иінності; студенти.

Puc. 1. Лim. 8.

Oksana Isayeva, Doctor of Sciences (Pedagogy), Professor of the Pedagogy and Innovative Education Department Lviv Polytechnic National University, Associate Professor of the Latin and Foreign Languages

Danylo Halytsky Lviv National Medical University

Hanna Shayner, Ph.D. (Pedagogy), Associate Professor of the Foreign Languages Department Lviv Polytechnic National University

\section{STUDENTS' HUMANITARIAN DEVELOPMENT AS A COMPONENT OF HIGHER EDUCATION SYSTEM}

The performance and quality of higher education has become an index of a country's capacity for its social and economic advances and innovations. Understanding the changes is rather challenging process due to the scope and complexity of those trends in the system of education.

Humanities education is one of the factors influencing the moral and ethical worldview of the individual as it considers conceptual approaches of scientists to understanding the phenomena of humanization and humanitarization of higher education. Humanitarian development characterizes the essence and genesis of humanization and humanitarization of higher education, clarifies its conceptual apparatus of the investigation. Humanitarian development also involves the recognition of the importance of the individual, his moral and ethical principles, and the formation of humanistic interpersonal relations providing actual tendencies of humanization and humanitarization of higher education.

Reforming of higher education requires considerable attention to students' humanitarian development as the disclosure of individual's potential to realize their intellectual, cultural, creative potential.

The strategy of humanitarian development of higher education system should be based on the integration and globalization processes as an important component of the formation of students'value orientations. And the criteria of morality, spirituality, humanistic values should be decisive for future professional activity.

Humanitarian development is focused on the formation of a modern competitive personality, harmonious development and realization of all his abilities, involves the formation and expansion of scientific and philosophical worldview of the person, formation and development of socio-personal and professional competencies. In order to provide high standards of higher education, education should provide students with the tools to develop their competences due to students' humanitarian development.

Keywords: humanitarian development; humanities; higher education; humanistic values; students.

П остановка проблеми у загальному вигляді. Показники та якість вищої освіти розглядаються як індекс спроможності країни, аби закласти фундамент ії соціального та економічного прогресу. Сучасний соціальний прогрес тісно пов'язаний 3 
інтелектуальним рівнем розвитку особистості, їі теоретичними і практичними навичками, компетенціями та вмінням творчо їх використовувати, а також етико-деонтологічними принципами. Адже успішний розвиток країни неможливий без власної ідентичності, не варто сподіватися і на прорив технологій за відсутності проєкту розвитку, формування і становлення особистості. Тому особливу увагу необхідно закцентувати на змісті, спрямованості та стратегії розвитку гуманітарної освіти у вишах, яка має безпосередній вплив на світогляд, розвиток $\mathrm{i}$ постання ідеї патріотизму нації та особистості зокрема.

Загальновідомо, що гуманітарна освіта $€$ одним з факторів формування морально-етичного світогляду особистості. Саме через нього забезпечується відтворення особистісної культури, тобто “картина світу” особистості стає вельми якісною, системною і всебічною та безпосередньо впливає на професійне становлення майбутнього спеціаліста, а саме його фахову культуру. Метою стратегії гуманітарного розвитку України є: формування вільної, забезпеченої всіма можливостями для самовиявлення, фізично й духовно розвиненої особистості, яка живе в гармонії із собою, іншими людьми, природним середовищем і навколишнім світом; удосконалення суспільного середовища на засадах безпеки й стабільності, національної та громадянської єдності; створення умов для функціонування національної культури, конкурентоспроможної і рівноправної серед культур інших народів світу [8], яку необхідно поетапно втілювати у закладах вищої освіти.

Проте відбувається втрата гуманістичного орієнтиру розвитку сучасного фахівця, простежується відхід від гуманістичних цінностей. Особливо це відбувається в системі вищої освіти, де гуманітарний розвиток витісняється на другорядний план, що і посилює розрив між власне освітою і просвітництвом студентів як еліти нації. Розуміння змін, що відбулися у вищій освіті за кордоном, вважаються досить складними з огляду на масштаби та складність цих тенденцій. Тому змінюються роль і зміст дисциплін соціально-гуманітарного циклу у вишах, адже кількість годин на них постійно скорочується.

Мета дослідження - обгрунтування основних напрямів впливу гуманітарного розвитку на формування особистості в умовах глобалізації.

Відповідно до мети дослідження визначено такі завдання:

- визначити сутність гуманітарного розвитку освіти для формування фахівців;

- сформувати етапи становлення особистості в умовах гуманітаризації.

Аналіз останніх досліджень і публікацій. Численні розвідки вітчизняних та зарубіжних науковців присвячено проблемам гуманітаризації підготовки майбутніх фахівців у ЗВО: Т. Байбара, Н. Бібік, В. Бондар, М. Вашуленко, П. Гусак, О. Дубасенюк, Г. Калінічева, М. Карпенко, Н. Кічук, А. Кучерявий, I. Мельничук, В. Мисюра. Особливої уваги заслуговують праці О. Савченко - формування гуманістичних цінностей здобувачів вищої освіти; А. Ярошенко формування духовних цінностей у вищій школі засобами гуманітарних наук; О. Вознюк становлення системи гуманітарних інтегрованих знань студентів технічних університетів; Г. Воронка, I. Оніщенко, Л. Яценко досліджували проблеми гуманітарної освіти; І. Кузнєцова, С. Романова розглядали аспекти гуманітаризації технічних знань; В. Астахова, Г. Бевз, О. Бондаревська, М. Каган, І. Козловська, Б. Лихачов, А. Степанюк студіювали проблему гуманітаризації на дидактичному рівні.

Виклад основного матеріалу й обгрунтування отриманих результатів дослідження. Сьогодення вимагає гуманістично центрованого напряму розвитку вищої освіти, тобто встановлення гармонійності та кореляції у навчанні природничоматематичних і соціально-гуманітарних дисциплін з метою розвитку фахівця як духовноморальної особистості. Адже гуманітарний розвиток передбачає визнання значущості особистості, iї морально-етичних принципів, а формування гуманістичних міжособистісних відносин забезпечує власне гуманітаризація освіти. Тому модернізація освіти стосується

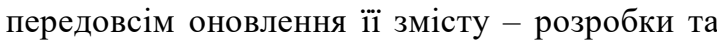
впровадження сучасних стандартів, вдосконалених навчальних програм i підручників, які передбачають гуманітарний розвиток, що забезпечує відбір, синтез і аналіз здобутої практичної інформації. Проте, існує думка щодо розчарування теоретиків і практиків педагогіки в можливості впливу гуманітарних наук на становлення особистості, формування стійких ціннісних орієнтацій, на виховання громадянської ідентичності [7] та стійкої позиції.

Погоджуємося із твердженням корифеїв педагогічних розвідок, а саме В. Андрущенка, В. Кременя, В. Лутай, котрі зазначають, що гуманітаризація вищої освіти - це відображення в освітньому процесі гуманістичних тенденцій розвитку суспільства, в умовах котрого людська особистість визнана найбільшою цінністю, що $є$ 
особливо актуальним в умовах сучасного техногенного розвитку нації а головною метою освіти розглядається формування гармонійно розвиненої особистості, яка має особисту і соціальну відповідальність за власні дії та вчинки. А в ширшому діапазоні-це продукт “формування розуму, характеру і фізичних здібностей особистості” [4] у процесі викладання соціальногуманітарних дисциплін.

Отож, гуманітарний розвиток - це сучасна модель, орієнтована на максимальне розкриття потенціалу кожної особи і соціуму загалом, створення гідних умов для реалізації інтелектуальних, культурних, творчих можливостей людини та нації [8]. Саме гуманітарні знання пов'язані з характерними й обумовленими умовами виникнення або прояву, a іноді неповторними, специфічними, невідтворюваними чи особливими процесами явищами, подіями та фактами. Тобто гуманітарна освіта повинна сформувати в особистості здатність до рефлексії, асертивності, самовираження, самоаналізу, самомотивації, самосвідомості тощо. Проте, декультуризація і дегуманізація сучасної молоді значною мірою $є$ наслідком виховання та освіти, радше - наслідком поганого або відсутності виховання й недосконалої освіти, тобто занепаду гуманітарного розвитку особистості.

Особливої уваги заслуговує твердження науковця Л. Гумільова, що гуманітарні науки можна розглядати у двох аспектах: “гуманітарні науки - це ті, що вивчають людину та ії діяння, а природничі науки вивчають природу живу, мертву і відсталу, тобто яка ніколи не була живою"; інший спосіб розгляду - це “поділ за способом вивчення первинної інформації. Тут можливі два підходи: читання книг або прослуховування повідомлень (легенд, міфів тощо) і спостереження, іноді 3 експериментом. Перший спосіб відповідає гуманітарним наукам, цариною яких є філологія. Другий - природничим наукам, які слід поділити на математизовані і описові. Математизовані мають справу 3 символами; описові - 3 феноменами" [5].

Загальновідомо, що пропонуються кардинальні зміни в гуманітарній сфері, які мають відбутися і в напрямі гуманізації освіти. Адже власне гуманізація передбачає гуманітарний розвиток студентів у політичному, економічному, соціальному та культурному вимірах, сприяє новій ролі гуманітарної освіти щодо можливостей для гармонійного розвитку, формуванню нової стратегії розвитку освіти в нових кризових умовах та впровадженню інноваційних технологій у навчальний процес. Науковець П. Автомонов виділяє два напрями, які називає вузьким і широким значенням гуманізації. У вузькому значенні гуманізація постає як орієнтація навчання на розвиток особистості. У широкому значенніце створення всіх умов “для розкриття здібностей особистості, задоволення її потреб в інтелектуальному, духовному, моральному й фізичному розвитку" $[1,185]$.

Уважаємо, що реформування вищої освіти вимагає значної уваги щодо гуманітарного розвитку студентів як розкриття потенціалу особистості для реалізації їх інтелектуальних, культурних, творчих можливостей за допомогою:

- впровадження інформаційно-комунікаційних технології;

- оптимізації принципів і правил основ доброчесності;

- розвитку фахової комунікації;

- формування навичок академічного письма;

- виховання морально-етичних і деонтологічних принципів;

- генерування ідей толерантності;

- формування академічної культури i середовища;

- створення умов для засад здорового способу життя.

Отож, пропонуємо власне наповнення моделі гуманітарного розвитку, ключові аспекти якої представлено на рисунку 1.

Безсумнівно, поділяємо твердження академіка В. Андрущенка щодо “органічного поєднання вивчення основ природничих наук й духовного профілю”, що, як вважає науковець, є “важливою характеристикою життєдіяльності європейських університетів" $[2,8]$. Тому стратегія гуманітарного розвитку системи вищої освіти повинна базуватися на інтеграційних і глобалізаційних процесах суспільства як важлива складова формування ціннісних орієнтацій студентів. А критерії моральності, духовності, гуманістичних цінностей повинні бути визначальними для майбутньої професійної діяльності.

Варто зазначити, що важливим є гуманітарний складник навчання, адже міжпредметна інтеграція відіграє важливу роль для укладання силабусів блоку соціально-гуманітарних дисциплін, використовуючи оновлені матеріали та сучасні методики і техніки викладання. До соціальногуманітарного блоку належать науки, які вивчають моральну, інтелектуальну, духовну, культурну, історичну й суспільну сфери діяльності, котрі вважаються базовими для становлення особистості чи подальшої кар'єрної діяльності. Адже навіть для найкращого фахівця технічного профілю, який хоче керувати людьми, але "не здобув гуманітарної освіти”, - “людина 3 їі 


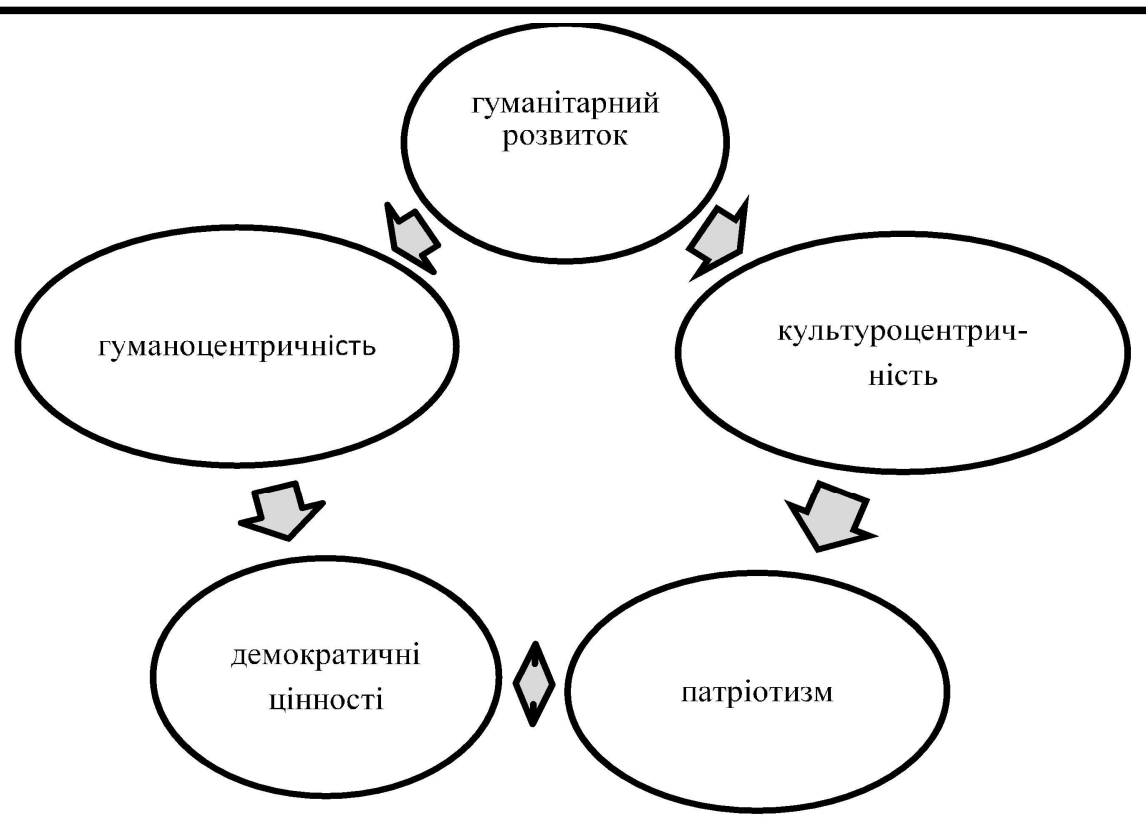

Рис. 1 Схема складових моделі

багатогранними потребами, зв'язками, а тим більше - емоціями, симпатіями, експектаціями залишиться ... “закритою книжкою” [3,9].

Висновок. Гуманітарна освіта орієнтована на формування сучасної конкурентоспроможної особистості, гармонійного розвитку та реалізацію всіх їі здібностей, передбачає формування й розширення науково-філософського світогляду особи, поглиблення світосприймання, формування й розвиток соціально-особистісних і фахових компетенцій. Для того, щоб забезпечити високі стандарти вищої освіти, навчання має забезпечуватися інструментами для розвитку гуманітарної компетенції студентів, яка включає і культурологічну складову. Адже “лише викладач, який має гуманістичний світогляд, необхідні особисті якості, педагогічну спрямованість, базу психолого-педагогічної підготовки, викладач, якому “комфортно” в своїй діяльності, може побудувати педагогічний процес в гуманістичному руслі і забезпечити гідну гуманітарну підготовку у технічному 3ВО" $[6,61]$.

3 метою вдосконалення професійнокваліфікаційних характеристик майбутніх фахівців необхідною провести переорієнтацію на оновлення методики викладання та шляхи удосконалення наповнення предметів соціально-гуманітарного блоку. Зміст соціально-гуманітарних предметів має бути зорієнтований на засвоєння абстрактних понять чи явищ, подальше їх практичне усвідомлення i застосування 3 метою креативного розв'язання проблем.

Перспективу подальших досліджень вбачаємо у вивченні компетенцій, що здобуваються у процесі викладання соціальногуманітарних дисциплін.

\section{ЛІТЕРАТУРА}

1. Автомонов П. П. Стратегічний принцип гуманізації вищої освіти і тактика його реалізації. Актуальні проблеми соціологї, психології, педагогіки: Збірник наукових праиьь. 2012. С. 184-188.

2. Андрущенко В. Основні характеристики європейської вищої освіти та можливості їх реалізації в системі освіти України. Вищза освіта Украӥни. № 4. 2010. С. 5-16.

3. Андрущенко В. Стратегія для освіти (За матеріалами звіту відділу філософії та прогнозування розвитку освіти Інституту вищої освіти АПН України, червень, 2006). Вища освіта Украӥни. № 3. 2006. С. 5-9.

4. Бауман 3. Образование - при, для и несмотря на постмодернити. Индивидуа-лизированное общество. 2002. С. 155-175.

5. Гумилев Л. Н. Конец и вновь начало. 2002. $386 \mathrm{c}$.

6. Луцик I. Г. Використання інтерактивних методів як засіб створення інтенсивного освітнього середовища. Новi технології навчання: науково-методичний збірник. М-во освіти і науки України, Інноваційних технологій і змісту освіти. № 46. 2007. С. 59-63.

7. Fisher J.B., Schumaker J.B., Culbertson J., Deshler D.D. Effects of a computerized professional development program on teacher and student outcomes. Journal of Teacher Education. № 61. 2010. C. 301-312. 
8. Концепція гуманітарного розвитку України : проект / Національний інститут стратегічних досліджень. URL: http://semadm.cg.gov.ua/ web_docs/36/2012/07/docs/Проект_Концепця\%20гуман-тарного \%20розвитку\%20Укра-ни^ $\ddot{\mathbf{i}} /$.

\section{REFERENCES}

1. Avtomonov, P. P. (2012). Stratehichnyy pryntsyp humanizatsiyi vyshchoyi osvity i taktyka yoho realizatsiyi [Strategic principle of humanization of higher education and tactics of its implementation]. Actual problems of sociology, psychology, pedagogy: Collection of scientific works. pp. 184 188. [in Ukrainian].

2.Andrushchenko, V.(2010). Osnovni kharakterystyky yevropeyskoyi vyshchoyi osvity ta mozhlyvosti yikh realizatsiyi v systemi osvity Ukrayiny [The main characteristics of European higher education and the possibility of their implementation in the education system of Ukraine]. Higher education in Ukraine. No. 4. pp. 5-16. [in Ukrainian].

3. Andrushchenko, V. (2006). Stratehiya dlya osvity (Za materialamy zvitu viddilu filosofiyi ta prohnozuvannya rozvytku osvity Instytutu vyshchoyi osvity APN Ukrayiny, cherven, 2006) [Strategy for Education (According to the report of the Department of Philosophy and Forecasting of Education Development of the Institute of Higher Education of the Academy of Pedagogical Sciences of Ukraine,
June, 2006)]. Higher education in Ukraine. No. 3. pp. 5-9. [in Ukrainian].

4.Bauman,Z.(2002). Obrazovaniye-pri, dlyainesmotrya na postmoderniti. Individualizirovannoye obshchestvo [Education - with, for and in spite of postmodernity. Individualized society].pp. 155-175. [in Russian].

5. Gumilev, L. N. (2002). Konets i vnov nachalo [The end and the beginning again]. 386 p. [in Russian].

6. Lutsyk, I. H. (2007). Vykorystannya interaktyvnykh metodiv yak zasib stvorennya intensyvnoho osvitn№oho seredovyshcha [The use of interactive methods as a means of creating an intensive educational environment]. New learning technologies: scientific and methodical collection. Ministry of Education and Science of Ukraine, Innovative Technologies and Educational Content. No. 46. pp. 59-63. [in Ukrainian].

7. Fisher, J.B., Schumaker, J.B., Culbertson, J. \& Deshler, D.D. (2010). Effects of a computerized professional development program on teacher and student outcomes. Journal of Teacher Education. No. 61. pp. 301-312. [in English].

8. Kontseptsiya humanitarnoho rozvytku Ukrayiny: proekt [The concept of humanitarian development of Ukraine: project]. National Institute for Strategic Studies. Available at: http://semadm.cg.gov.ua/ web docs/36/2012/07/docs/Proekt Kontseptsya $\% \overline{2} 0$ human-tarnoho $\% 20$ rozvytku $\% \overline{20 U k r a-n y}{ }^{\wedge}$ yi/ [in Ukrainian].

Стаття надійшла до редакції 21.09.2021

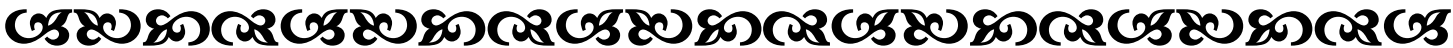

"Немає години, непридатної для занять корисними науками, $і$ хто помірно, але постійно вивчає предмети, корисні як в цьому, так $i$ в майбутньому житті, тому навчання - не труд, а втіха... Хто думав про науку, той ^юбить ї̈, а хто й ^юбить, той ніколи не перестає учитись, хоча Бзовні він $і$ здавався бездіяльним".

Тригорій Сковорода уқрайнський просвітитель-гуманіст, болособ, поет, педагог

“Заняття наукою живлять юність і приносять насолоду старості, приқрашають в щасті, служать притулком і розрадою в нещасті".

Iичерон

давньоримський політичний діяч, видатний оратор, філособ та літератор

“Фля вченої й освіченої людини жити - значить мислити”.

Квінт Ұбиерон

давньоримський оратор, політик

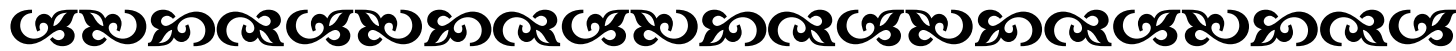

